\title{
Jean Baudrillard's Karl Marx - Productivist Ideology, And The Future of the Left
}

\author{
Gerry Coulter
}

\section{Introduction}

The grand Marxist promise has ended (Baudrillard, 1985:95).

Marx believed that in economics and its dialectical procedure he found fundamental agency, all he found was what haunts it (Baudrillard, 1993a:237).

The place of Marx's writings in scholarly circles has changed greatly over the past 40 years - the four decades in which Baudrillard published over 40 books. Marx found his way into a significant place in 29 of these texts. Baudrillard's passage through Marx is telling of important developments in intellectual culture in recent times. None of these is any more important than the future of Marx's writings. While many in the West continued to believe that Marx's ideas could provide solutions to capitalist political economy, Baudrillard was among the first on the Left to become deeply dissatisfied with Marx's writings. The break with Marx was an important part of Baudrillard's coming to grips with radical uncertainty - an uncertainty which accelerates and envelopes all of us in the continuing mutations of fast (hyper) capitalism.

For anyone interested in the future of Marx, Baudrillard's encounter with him after 1968 is crucial. Just as Baudrillard was not especially comfortable in the "post-Marxist" world - many scholars who are not fond of Baudrillard have come to recognize that the Marx we have today, for better or worse, is one that has passed through Baudrillard and his contemporaries. This paper hopes to stimulate thought concerning the future of Marx (in postBaudrillardian times) by examining Baudrillard's writing about Marx(ism) at two levels: 1) His more general challenges to Marx and, 2) his more specific charges concerning Marx's failure to significantly surpass bourgeois analysis. For the Left to survive it is going to have to answer many challenges - among them, on the scholarly side, none are more daunting than those posed by Baudrillard. In my time Baudrillard would become Marx's radical other.

\section{Baudrillard's General Challenge to Marx}

Baudrillard did not believe in the death of Marxist thought. Responding to a question in 1993 he said that Marx's thought "continues to make a difference even though it does not have the impact it once had politically" (Gane, 1993:203). He told the same interviewers that "Marx's analysis was certainly influential upon my work, but I immediately came to question it, became ambivalent about it, and distanced myself from it" (Ibid.:20). He also told François L'Yvonnet that his break with Marx came during the writing of the Mirror of Production (Baudrillard, 2004:20). This is correct but the break is also detectable in his work theorizing our system of objects and the consumer society from 1968-1970. 
For Baudrillard the general problem with Marx is that time has, in important ways, passed his analysis by. For my part I have no doubt that Baudrillard would have preferred to live in a time when Marx's writings were fresh and new, when politics had more meaning, and there were more things in which believe. However, Baudrillard like each of us, had to face the challenges of contemporary life and the revolution of our time which is, as he said so well: "the uncertainty revolution" (1993b:43).

Baudrillard's assessment of Marx is intricately connected to his own quest to embrace the challenge of radicality in uncertain times. This led Baudrillard to write, what were for Marxists, heretical words in his major work on Marx: "Marx is not in an historical position to speak the truth" (1975:117). For Baudrillard, Marx was merely the owner of "a perspective" which was resigned to one view concerning the "laws of history and dialectics" (Ibid.:162). As early as 1973 Baudrillard [who adopted a political detachment even before May 1968] (Baudrillard in Gane, 1993:74), wrote that all of Marx's concepts must be questioned (1975:21), and that what is required is a critique of the structural limits of Marx's assessment (Ibid.:65). All of this, which was so inflammatory for Marxists in the 1970's seems so tame to us today. Baudrillard's passage through Marx has been one of the signs of our times.

At the more general level then, Baudrillard's challenge to Marx is that his writing no longer explains contemporary society. In this, Marx, like all theorists, succumbs to unavoidable reversibility - the inversion which is the fate of every theory and critique (Baudrillard, 1975:50). Baudrillard was also among the first to point out that we had already entered a post-Marxist age (in Gane, 1993:20). For Baudrillard a kind of revolution had taken place in value which Marx's analysis was unable to explain (1993a:6). What he meant by this is that Marx was focused on "classical" value - the more natural stage of use-value and the commodity stage of exchange value. Today value has passed through a structural stage (sign value), and is entering a fractal stage - a point of no reference at all "where value radiates in all directions" (1993b:5). As he told Philippe Petit: "we lost use-value, then good old exchange value, obliterated by speculation, and we are currently losing even sign value for an indefinite signaletics" (1998b:3).

Baudrillard also noted, contra Marx, that "capital has not lurched from one crisis to another (2002:23). In Baudrillard's assessment, Marx was turned away from radical exigency (as were many 19th century thinkers), by the need he felt to devise historical laws (Baudrillard, 1975:161). Marx thus adopted a law of necessity and the idea of perpetual transcendence (Ibid.:61). Post-feudal history is transhistoricized by Marx (universalized) as the class struggle and the mode of production is projected into all of history (Ibid: 47, 67). This mindset, combined with a belief in dialectics, allows Marx to fabricate labour power and production into the equivalent of historical reason working itself out (Baudrillard, 1993a:12). In Marx then, Baudrillard finds the negativity of labour lost as it has been raised to an absolute value (1975:34) and so, within Marx's writing, labour becomes an ideological concept (Ibid.:43). Marx also, says Baudrillard, "eliminates the analysis of ideological labour,"(1981:89) and, in the end, leaves us with an enigma which Baudrillard expresses in the devastating question: "how is surplus value born?" (1975:26).

For Baudrillard, Marx constructed a theory which is "irredeemably partial" (1981:165) lacking a truly "radical analysis of labour and production" (1975:21-51). Among the most vital of the more general problems Baudrillard had with Marx is that "ideological priority is given to exchange value" (Ibid.:24). Marx thus fails to conceive of social wealth being founded by other than labour and production (Ibid.:29). Marx's writing is thus incapable of doing that which it promises - theorizing total social practice (Ibid.:152) and is entirely incapable of "responding to a social process that far exceeds material production" [such as contemporary mass media] (1981:165-66). Baudrillard thus radically departs with Marx in developing his own understanding of the importance of symbolic exchange. For Baudrillard symbolic exchange concerns reversibility - the fact that all systems eventually tend to break down as the result of their own success - and operates at a radically different level than Marx's understanding of exchange value (1975:51). Capitalism itself is not the product of the failure of feudalism but of its success. It is not dialectics that will end capitalism in Baudrillard's view, but only capitalism itself that can end capitalism. As for dialectics, in our time of hypertelia, proliferation, and indeterminacy, they are finished for Baudrillard. Transcendence, that most urgent Marxist concept, is no longer viable (2001:51). For Baudrillard, the world no longer has a chance of escape into an upper realm of Truth, God, the Law, or the Idea, but merely the lower reaches of immanence (1990:86). This is one of the more problematic aspects of our time which make it so unbearable (2005:25).

Baudrillard also questions the place of freedom in Marx's analysis. He says that for Marx, freedom is based on the domination of nature (a very capitalist idea) (1975:67), and that Marx makes a promise of liberation out of what is (and has repeatedly been shown to be since Marx's time) “a process of repression” (Ibid.:154). What happens with Marx, and Marxists who follow him, is that a great irony occurs - those who seek to revolutionize class struggle actually put an end to it "burying it under a theoretical project" (1987:13). It is this very contingent, determinist, universalized theoretical project - ideologically committed to productivism via labour and man's command of nature, that leads us, in Baudrillard's assessment, to the deeper and more specific problem with Marx: his failure to provide 
an alternative to productivism (1981:90).

\section{Marx's Failure to Provide An Alternative To Capitalism}

Baudrillard ultimately finds Marx able to offer a wide ranging criticism of capitalism in his own time but one which lacks the kind of radicality we need today. And, even in his analysis of his own time, Marx is further charged with misunderstanding some of the capitalist formations then extant (1975:106 ff). It is, in Baudrillard's terms, the "production of the production system" which escapes Marx (Ibid.:66). Baudrillard has a very good point here as in Marx there is a constant assumption (it is intrinsic to his understanding of labour and nature), that production is taken for granted - what is wrong is merely how it is organized. Marx's thought is infected with the virus of the past 500 years - a commitment to productivist ideology. Baudrillard quite rightly gets to the core of some very important implications of Marx's thought - especially the obvious fact that production (as a form) is not subjected by Marx to radical analysis (Ibid.:20). Baudrillard says that Marx has kind of “theoretical allergy to everything that isn't material production and productive labour" (1981:167). Marx's theory is, for Baudrillard, one that "analyzes the social field that it produces" (1993a:221-22).

This leads Baudrillard to a series of insights concerning Marx, which were for a time in the 1970's and 1980's, distinctive to him as a theorist. Baudrillard's radical challenge to Marx is that his perspective suffers (along with a commitment to productivism and over-determination of man as producer (1975:31-32)), the same humanist virus which bourgeois thought shares (Ibid.:49). Marx's very analysis, despite itself, is charged by Baudrillard with "assisting the cunning of capital", "contributing to the capitalist mythology", and "reproducing the system of political economy” (1975:31; 1981:134). In its commitment to continued productivism (post revolution), Marxism finds itself ironically in the same position as bourgeois economics (1981:115). By centering itself (from the Paris Manuscripts of 1844 onwards (Marx, 1977)) on “man’s productive vocation” (Baudrillard, 1981:36), Marx's assessment of capitalist society succumbs to a dialectic and Christian ethic which produces a critique which is not radical, but rather, plays a key role in reproducing the existing system of political economy (Ibid.:36-37). It is difficult to argue with Baudrillard on this point as every single authority which attempted to bring about a revolution based on Marx's ideas did indeed reproduce a state-capitalist version of capitalist political economy (Ibid.:67).

Beyond this devastating problem, Baudrillard says that Marx was unable to foresee "that capital would, in the face of an immanent threat to its existence, launch itself into an orbit beyond the relations of production, and political contradictions, to make itself autonomous, to totalize the world in its own image" (1993b:10). Baudrillard here describes our contemporary condition as "transeconomic"... "where classical economics gets lost in pure speculation" (2000:52). For Baudrillard then, Marx makes the mistake of attempting to offer a radical critique of political economy in the form of political economy (1975:50). What Marx does then, is to produce not a radical alternative to productivism - but merely the mirror of capitalist production (Ibid.:152). Marx's illusion, and all writing ultimately succumbs to illusion for Baudrillard, is that he believed in the "possibility of revolution within the system" (1993a:35). This leaves us with the difficult fact that Marx's theory, when we cut it to the bone as Baudrillard does, "never stopped being on the side of capitalism" (Baudrillard in Genosko, 2001:95). This is because Marx's thought "retains concepts which depend on the metaphysics of market economy" (1975:59). Marx and his followers were thus never able to go beyond capitalism (some form of state capitalism based on productivism) and a range of neoChristian and humanist understandings of labour. In the contemporary Baudrillard finds those who were to be the heroes of the revolution turned into the silent but tired anti-heroes of consumption (1998a:182).

\section{Conclusion}

Among the insights we gain from Baudrillard's writings on Marx is that capital (its historical function) produces the social. In this Marx was right. But when the objective determinations of capital lose their force, Baudrillard correctly points out: "the social will not overcome capital according to some dialectical movement". Importantly for Baudrillard, this means that the Left died "of the same causes as power" (Baudrillard in Genosko, 2001:97). This is also why 'Left' and 'Right' have largely disappeared as useable categories and why we have become increasingly dissatisfied with (and indifferent to) them. If we take Baudrillard's understanding of Marx to its logical conclusions we can provocatively say that the Left was never really anything more than a prosthesis of the right (Ibid). All the Left 
seems able to do now, especially in the age of ecological-correctness, is play the sad role of "setting up models of pacified socialization" (1993a:173). This has become, pathetically, the fate of numerous progressives (including many unionists, feminists, and environmentalists) who seek to revive public morality or pitifully beg at the knee of the Law. Others merely remain "stuck in denunciation" (2002:206). As much as the Left persists at all it does so in many ways as a last vestige of Marx - defunct and "spontaneously doing the work of the right" (1994:16). The children of 1968 have gone over to ecological efforts to prolong capitalist expansion and serve productivism in new ways.

Another implication of our post-Marx(ist) condition is that we are left with a circumstance in which "people are no longer fighting alienation but a kind of dispossession" (1998b:19). We are no longer combating the spectre of alienation, but that of hyper-reality (1996:66). Baudrillard did not like our contemporary condition but he did his best to thrive as a thinker and a writer while coming to grips with its radical uncertainty. Writing, beyond the political, after any possibility of transcendence, was his post-Marxist politics. As he said with such heart rendering poignancy for a Parisian man of the Left of his generation: "there are no children of May" (Baudrillard in Genosko, 2001:74).

Is a post-Marxist, post-Baudrillardian Marxism possible? Of course not. But those on the Left who in earlier times might have been Marxists can now, through a serious engagement with Baudrillard, challenge the productivist ideology on which Marx foundered and capitalism continues to proliferate.

Through a serious engagement with Baudrillard's challenge to Marx the Left can find its last chance to be truly radical.

\section{References}

Baudrillard, Jean. [1973] 1975. The Mirror of Production. St. ---- [1997] 1998b. Paroxysm: Interviews with Philippe Petit. New Louis: Telos. York: Verso.

---- [1972] 1981. For A Critique of the Political Economy of the Sign. St. Louis: Telos.

--- 2000. The Vital Illusion. New York: Columbia University Press.

--- (1985). “The Divine Left” in Gary Genosko. The Uncollected Baudrillard. London: Sage, 2001.

---- [1977] 1987. Forget Foucault. New York: Semiotext(e).

--- [1987] 1990. Cool Memories I, 1980-1985. New York: Verso.

---- [1999] 2001. Impossible Exchange. New York: Verso.

---- [2000] 2002. Screened Out. New York: Verso.

-.-- [2001] 2004. Fragments: Conversations with Francois L'Yvonnet. New York: Routledge.

-.-- [1976] 1993a. Symbolic Exchange and Death. London: Sage.

---- [2004]. 2005. The Lucidity Pact Or The Intelligence of Evil. London: Berg.

--- [1990] 1993b. The Transparency of Evil: Essays on Extreme Phenomena. New York: Verso.

-.-- [1981] 1994. Simulacra and Simulation. Ann Arbor: The University of Michigan Press.

---- [1995] 1996. The Perfect Crime. New York: Verso.

Gane, Mike (Editor). 1993. Baudrillard Live: Selected Interviews. London: Routledge.

Marx, Karl. [1844] 1977. Economic and Philosophic Manuscripts. Moscow: Progress Publishers.

--- [1970] 1998a. The Consumer Society. London: Sage. 